\title{
ETHNOPHARMACOLOGICAL EVALUATION OF MEDICINAL PLANTS FOR CYTOTOXICITY AGAINST VARIOUS CANCER CELL LINES
}

\author{
RUCHI SINGH THAKUR, BHARTI AHIRWAR* \\ Institute of Pharmaceutical Sciences, Guru Ghasidas Vishwavidyalaya, Bilaspur (C. G.), India \\ Email: gaurhari7@gmail.com
}

Received: 25 Jan 2017 Revised and Accepted: 31 Mar 2017

\begin{abstract}
Objective: To evaluate the cytotoxic potential of leaves and seeds of Hibiscus sabdariffa L., fruit juice of Phyllanthus emblica, rhizomes of Dryopteris cochleata and flowers of Caesalpinia decapetala (Roth) Alston along with the chemical profiling of the most toxic extract through Gas-mass spectroscopy-MS technique.
\end{abstract}

Methods: The hydroalcoholic extract of the selected crude drugs was prepared by maceration method and the extracts were undergone through phytochemical analysis. The cytotoxic activity of the hydroalcoholic extract was performed against four cancer cell lines i.e. liver (HepG2), breast (MCF7), prostate (PC-3) and leukemia (HL60) using sulphorhodamine B assay. The hydroalcoholic extract of Caesalpinia decapetala flowers was profiled through using gas mass spectroscopy.

Results: The results confirmed that Phyllanthus emblica inhibited HL60 cancer cells at the dose of $35.6 \mu \mathrm{g} / \mathrm{ml}$ and show dose-dependent growth inhibition. The flowers of Caesalpinia decapetala inhibited nearly fifty percent of HL60 cancer cells at very low dose i. e $10 \mu \mathrm{g} / \mathrm{ml}$. The analysis of Caesalpinia decapetala flowers shows the presence of diterpenoid furanolactones, bufadienolides, polycyclic enones, and androsterone.

Conclusion: The fruit juice of Phyllanthus emblica and flowers of Caesalpinia decapetala showed good inhibitory activity against HL60 cancer cell line. The use of Phyllanthus emblica in herbal medicine is justified. The data obtained impelled to further assess the in vivo efficacy of Caesalpinia decapetala flowers for anticancer activity.

Keywords: Bufadienolides, Adriamycin, Sulphorodamine, Rhizomes, Cytotoxicity, Androsterone, Diterpenoid, Flowers

(C) 2017 The Authors. Published by Innovare Academic Sciences Pvt Ltd. This is an open access article under the CC BY license (http://creativecommons.org/licenses/by/4.0/] DOI: http://dx.doi.org/10.22159/ijpps.2017v9i5.17289

\section{INTRODUCTION}

Natural compounds obtained from plants, animals, and microorganisms contain a wide variety of chemical constituents. These diverse ranges of natural compounds turn boon for the medical industry. The history of traditional medicine system laid the foundation of existing modern medicine system. Plants are an integral part of traditional medicine and proved their significance in modern medicine system [1]. In the traditional medicine system, the crude extract of various herbal plants is used for the treatment of various disease, whereas in the modern medicine system, pure bioactive molecules obtained from plants are used to target the specific receptors of the body for the treatment of a disease. The adverse side effects of modern medicine due to multiple-drug resistance and no specificity to cancer has renewed the interest in herbal medicine and tailor-made therapy respectively [2]. Considering the documented reports, $60 \%$ of the anticancer drugs are derived from plants. Some of the well-known bioactive compounds used in the cancer treatment are camptothecin, vincristine, vinblastine, and taxol. The chemical modification of the natural compounds has given us many semisynthetics and synthetic drugs such as etoposide, paclitaxel etc. On the contrary, there are several lines of evidence show that whole extract of plant drugs are more effective than isolated compounds such as extracts of Phyllanthus emblica, Terminalia chebulica etc [3].

Cancer is the major cause of death in the world. Middle and lowincome countries contribute $60 \%$ of all cancers; report suggests that 13.2 million death are expected to occur by 2030 [4]. In 2012, total 1015 new cases of cancer and 683 death were reported in India [5]. Currently, treatment given for cancer patient includes radiation therapy, surgery, and chemotherapy, nevertheless, the major concerned about the chemotherapy is to reduce the side effects and multiple drug resistance; for the matter of that plant-derived cytotoxic drugs have attracted researchers to explore new phytoconstituents which have potential to treat cancer, coupled with lesser side effects, affordability and can act on multifaceted targets of the cancer cell.

The Chhattisgarh state of India is well known for its flourish flora and large forest area. A variety of medicinal plants from the forest of Chhattisgarh has been used by the traditional healers (baigas) for the treatment of various disease. The present study is designed to investigate some plants, for the search of potential for the cytotoxic activity and to give scientific support to the knowledge of traditional healers. In the current experiment, we have collected seeds and leaves of Hibiscus sabdariffa L., rhizomes of Dryopteris cochleata, fruit juice of Phyllanthus emblica, and flowers of Caesalpinia decapetala (Roth) Alston from Chhattisgarh to evaluate the potential for anticancer activity.

Hibiscus Sabdariffa L. is perennial shrub belongs to family Malvaceae. Hibiscus Sabdariffa L. showed antihypertensive, hepatoprotective, antibacterial, antihyperlipidemic and anti-atherosclerotic activity. A decoction of seeds is used traditionally in indigestion, dysuria nation, antitumor and as an antioxidant [6, 7]. Phyllanthus emblica is also known as Emblica officinalis belongs to family Euphorbiaceae. It is a rich source of vitamin $\mathrm{C}$ and considered as chemomodulatory, antioxidant, free radical scavenging, antiinflammatory, antimutagenic, radio modulatory and immunemodulatory [8]. Due to its rich phenolic compounds and diterpenoids, it has been frequently tested for anticancer activity.

Dryopteris cochleata is a pteridophyte which belongs to family Dryopteridaceae. It is extensively used by traditional healers as antidotes for snake bite and dog bite. Rhizomes are rich in flavonoids and phenolic contents and so it shows high antioxidant activity. Root juice is used in amoebic dysentery, while rhizomes are given for treatment of rheumatism, leprosy, epilepsy and wound ulcers. Leaves have antioxidant, free radical scavenging activity and antibacterial activity [9]. Caesalpinia decapetala (Roth) Alston belongs to family Fabaceae. It is traditionally used as antiinflammatory and immunomodulatory [10]. Previous studies reported that it has antioxidant, antifertility, antipyretic and 
antitumor activity. Roots have anticancer activity against human gastric carcinoma cell line MGC-803. This is the first study to evaluate its flowers for anticancer activity. All the above plants were selected on the basis of ethnobotanical data.

\section{MATERIALS AND METHODS}

\section{Collection, authentication, and drying of plant material}

The plant parts were collected from Achanakmar-Amarkantak bioreserve of Chhattisgarh, India. The selected plants for the study were identified and authenticated by the Department of Botany, Guru Ghasidas Vishwavidyalaya, Bilaspur, Chhattisgarh. The crude drugs were dried, coarsely powdered and stored in air tight containers. Powdered crude drug of Hibiscus sabdariffa L., Dryopteris cochleata and Caesalpinia decapetala (Roth) Alston were macerated with 50\% ethanol at room temperature for three days. The extracts were filtered and dried below $40^{\circ} \mathrm{C}$, while dried fruit juice of Phyllanthus emblica was used as such.

\section{Chemicals and reagents}

Ethanol, dimethylsulfoxide, foetal bovine serum, glutamine, sulphurhodamine solution, trizma base, hydrochloric acid, sulphuric acid dragendorff reagent, mayer's reagent, wagner's reagent, picric acid, pyridine, fehling solution $\mathrm{a}$ and $\mathrm{b}$, vanillin, magnesium turning, sodium nitroprusside, ferric chloride, sodium hydroxide, lead acetate, ninhydrin, benedict's reagent, nitric acid, $\alpha$-naphthol, chloroform, glacial acetic acid and potassium dichromate, were purchased from sigma aldrich. All the chemicals and solvents used were of standard analytical grades.

\section{Phytochemical screening}

All the plant extracts were undergone through preliminary phytochemical screening, for the identification of major phytoconstituents.

\section{In vitro evaluation of cytotoxicity against an array of cancer cell lines}

Sulphorhodamine B assay was performed to evaluate the cytotoxicity of the extracts against various cancer cell lines [11]. In the present experiment, cell lines were grown in RPMI 1640 medium containing $2 \mathrm{mmol} \mathrm{L-glutamine}$ and $10 \%$ fetal bovine serum. Grown cells were inoculated in 96 microtitre plate and incubated for $24 \mathrm{~h}$ at $37{ }^{\circ} \mathrm{C}, 95 \%$ air, $100 \%$ humidity and $5 \% \mathrm{CO}_{2}$.

\section{Preparation of samples}

Extracts were dissolved in dimethyl sulfoxide to make $100 \mathrm{mg} / \mathrm{ml}$ concentration and further diluted with distil-water to form $1 \mathrm{mg} / \mathrm{ml}$ concentration. The diluted samples were stored in frozen condition. Frozen extracts were thawed and diluted with complete medium containing test article to make $100 \mu \mathrm{g} / \mathrm{ml}, 200 \mu \mathrm{g} / \mathrm{ml}, 400 \mu \mathrm{g} / \mathrm{ml}$ and $800 \mu \mathrm{g} / \mathrm{ml}$ concentration. Aliquots of $10 \mu \mathrm{g} / \mathrm{ml}$ from different extract concentrate were added in microtitre well-containing $90 \mu \mathrm{l}$ of the medium resulting into the dilutions of $10 \mu \mathrm{g} / \mathrm{ml}, 20 \mu \mathrm{g} / \mathrm{ml}, 40$ $\mu \mathrm{g} / \mathrm{ml}$ and $80 \mu \mathrm{g} / \mathrm{ml}$.
Plates were incubated for $48 \mathrm{~h}$, cold TCA was added in plates to terminate the assay. For fixing the cells in situ $50 \mu \mathrm{l}$ of $30 \%(\mathrm{w} / \mathrm{v})$ cold TCA was added in plates and incubated at $4{ }^{\circ} \mathrm{C}$ for $60 \mathrm{~min}$. The supernatant was removed and plates were washed 5 times and air dried. For staining, $50 \mu \mathrm{l}$ of sulphorhodamine solution $(0.4 \%$ in $1 \%$ acetic acid) was added, plates were incubated at room temperature for $20 \mathrm{~min}$. The unbound dye was recovered and plates were washed five times with $1 \%$ acetic acid to remove residual dye and air dried. Trizma base $(10 \mathrm{M})$ was added to remove the bound stain, finally, absorbance at $540 \mathrm{~nm}$ and $690 \mathrm{~nm}$ were read on the plate reader. The percentage growth of cells was calculated by comparing test wells with control wells on a plate-by-plate basis. The percent growth was expressed as the ratio of average absorbance of the test well to the average absorbance of the control wells multiplied by 100.

The percentage growth of cells by each extract was calculated by taking six absorbance measurement i. e time zero $\left(\mathrm{T}_{\mathrm{z}}\right)$, control growth (C) and growth in test samples for four concentrations $\left(\mathrm{T}_{\mathrm{i}}\right)$, then, percentage growth was calculated as $[T i \div C] \times 100 \%$. Whereas, growth inhibition $\left(\mathrm{GI}_{50}\right)$ i.e. drug concentration resulting in a $50 \%$ reduction in the net protein increase was calculated by $[(T i-T z) \div(C-T z)] \times 100=50$; drug concentration resulting in total growth inhibition (TGI) was calculated from $\mathrm{Ti}=\mathrm{Tz}$. The $\mathrm{LC}_{50}$ value indicating the net loss of $50 \%$ cells following treatment was calculated from $[(T i-T z) \div t z] \times 100=-50$ The GI ${ }_{50}$ value $\leq 20 \mu \mathrm{g} / \mathrm{ml}$ is considered to exhibit the cytotoxic activity for all the five extracts $[11,12]$.

\section{Identification of components by gc-ms analysis}

GC-MS analyses were carried out by dissolving a Caesalpinia decapetula flowers aliquot in methanol. The extract was analyzed by using gas chromatography-mass spectroscopy on Agilent's (Agilent Technologies, Palo Alto, CA) 7890 GC system with 5975C inert XL EI/CI MSD with triple detector equipped with a firmware version A.01.13 and software driver version 4.01(054) gas chromatography with FID. The column used is Agilent's 19091S-433:325C: 25 meters* 320 micrometers*0.25 micrometers. Helium was used as a carrier gas with a flow rate of 1.1 $\mathrm{ml} / \mathrm{min}$ and program commenced at $60^{\circ} \mathrm{C}$ and held for $0.5 \mathrm{~min}$ and then raised to $275^{\circ} \mathrm{C}$ at a rate of $40^{\circ} \mathrm{C} / \mathrm{min}$ with a final hold time of $10 \mathrm{~min}$ Data was acquired by NIST library.

\section{RESULTS}

The present study was designed to evaluate the cytotoxic activity of hydroalcoholic extracts of seeds and leaves of Hibiscus sabdariffa L., flowers of Caesalpinia decapetala (Roth) Alston, rhizomes of Dryopteris cochleata, and dried juice of Phyllanthus emblica fruits.

\section{Phytochemical screening}

The hydroalcoholic extract was prepared through using maceration method. The phytochemical analysis of all the plant extracts confirmed the presence of general phytochemical constituents viz. glycosides, tannins, flavonoids, amino acids, proteins, steroids, carbohydrates, reducing sugar, monosaccharides, a pentose sugar, fats and oils (table 1).

\section{Measurement of endpoint}

Table 1: Phytochemical analysis of plants extract

\begin{tabular}{|c|c|c|c|c|c|c|}
\hline $\begin{array}{l}\text { S. } \\
\text { No. }\end{array}$ & $\begin{array}{l}\text { Phyto- } \\
\text { constituents }\end{array}$ & $\begin{array}{l}\text { Hibiscus sabdariffa } \mathrm{L} \text {. } \\
\text { Leaves }\end{array}$ & $\begin{array}{l}\text { Hibiscus sabdariffa } \\
\text { L. Seeds }\end{array}$ & $\begin{array}{l}\text { Caesalpinia decapetala } \\
\text { (Roth) Alston Flower }\end{array}$ & $\begin{array}{l}\text { Dryopteris } \\
\text { cochleata Rhizome }\end{array}$ & $\begin{array}{l}\text { Phyllanthus } \\
\text { emblica } \\
\text { Fruit juice }\end{array}$ \\
\hline 1 & Alkaloids & - & - & - & - & ++ \\
\hline 2 & Glycosides & + & - & + & ++ & + \\
\hline 3 & Tannins & +++ & + & +++ & +++ & +++ \\
\hline 4 & Flavonoids & + & +++ & + & +++ & +++ \\
\hline 5 & Steroid & - & - & + & - & + \\
\hline 6 & Proteins & ++ & + & ++ & ++ & + \\
\hline 7 & Carbohydrate & - & - & - & + & ++ \\
\hline 8 & Reducing sugar & - & + & + & +++ & + \\
\hline 9 & Monosaccharides & - & - & + & - & + \\
\hline 10 & Pentose sugars & - & - & - & + & + \\
\hline 11 & Fats and oils & +++ & +++ & ++ & + & + \\
\hline
\end{tabular}

+++ = Highly present; + = Moderately present; -= Absent 


\section{Cytotoxic activity}

Cytotoxicity of the selected plants against four cancer cell lines i.e. HepG2, MCF7, HL60, and PC3 was investigated by using sulphorhodamine B assay. To determine the cytotoxic potential of the extracts, $\mathrm{GI}_{50}$ (50\% growth inhibition), TGI (total growth inhibition) and $\mathrm{LC}_{50}$ values were observed. Adriamycin was used as standard drug. The dried fruit juice of Phyllanthus emblica showed a dose-dependent inhibition of cancer cell growth. It inhibited fifty percent of the HL60 cancer cells and the total cell growth at the dose of $35.6 \mu \mathrm{g} / \mathrm{ml}$ and $75.8 \mu \mathrm{g} / \mathrm{ml}$ respectively, it suggest that, at higher dose it may show significant cytotoxicity, which is in accordance with the study reported that extract enhances cytotoxicity in dosedependent manner $[13,14]$. The dried juice of Phyllanthus emblica did not show significant inhibition on other cancer cell lines. The rhizomes of Dryopteris cochleata and seeds and leaves of Hibiscus sabdariffa L. showed the absence of significant inhibition of cancer cell growth on any of the selected cancer cell lines (fig. 1). The negative results of these plants are in accordance with the absence of cytotoxicity against selected types of cancer cells, the difference in extraction procedure or extraction solvents.

The flowers of Caesalpinia decapetula showed nearly 50\% control growth of HL60 cells at the dose of $10 \mu \mathrm{g} / \mathrm{ml}$, but the cytotoxicity decline with the increase in dose concentration. The results of hydroalcoholic extracts of Caesalpinia decapetula flowers prompted to identify the compounds present in Caesalpinia decapetula flowers, by using gas chromatography-mass spectroscopy.

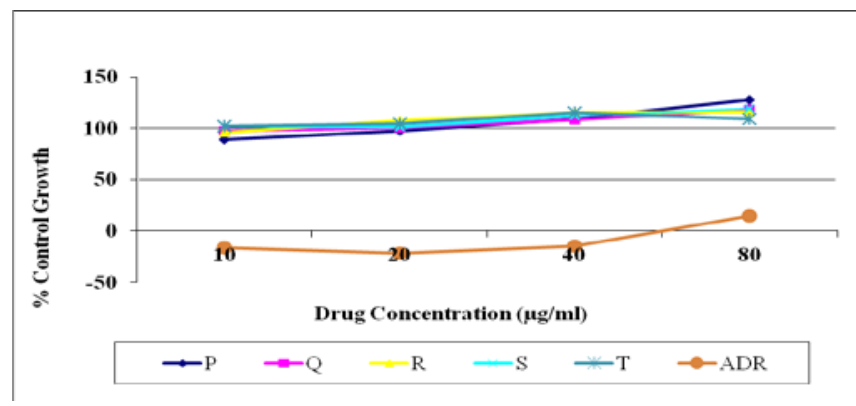

A

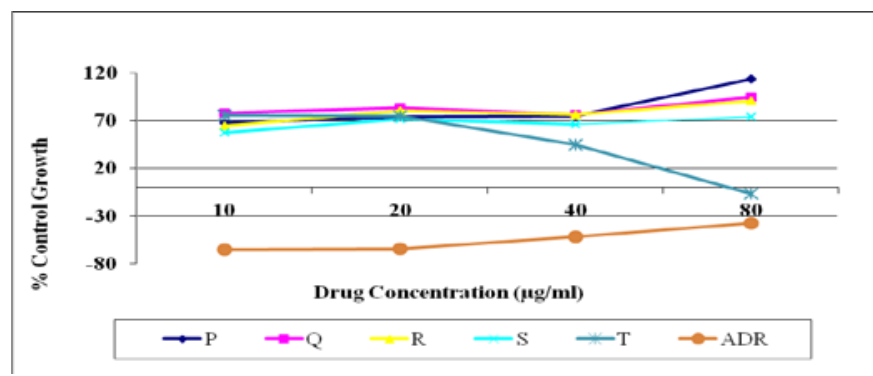

B
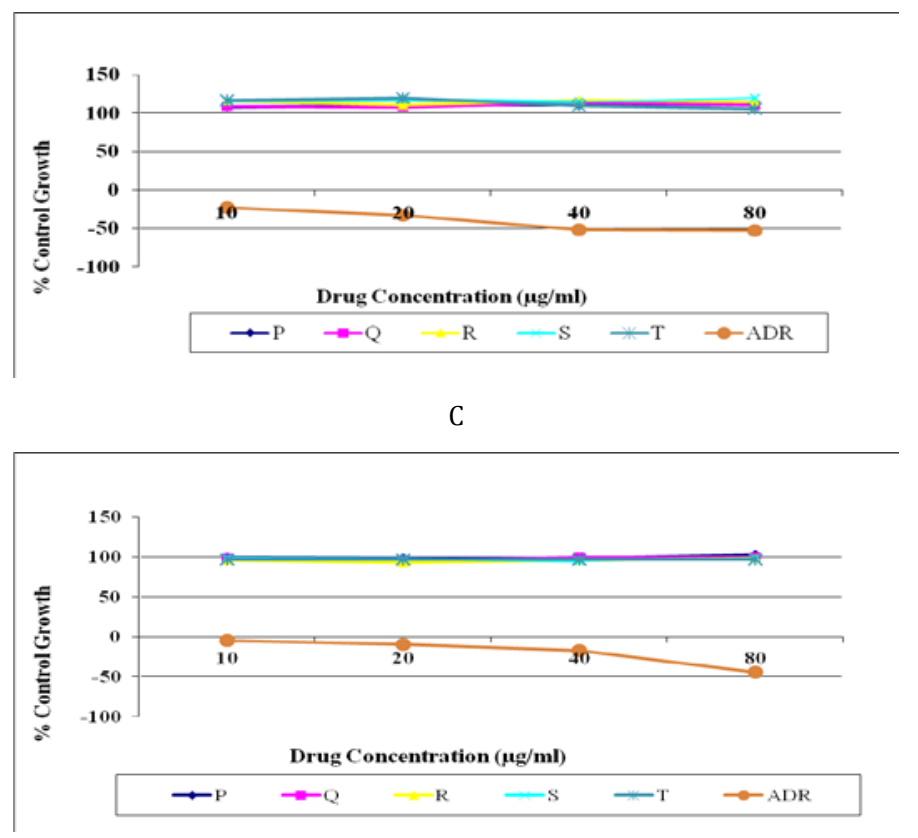

D

Fig. 1: Percent growth of (A) Hep-G2, (B) HL60, (C) PC-3, and (D) MCF-7 cancer cells with increasing concentration of extracts. P= hydroalcoholic extract of Dryopteris cochleata, $\mathrm{Q}=$ hydroalcoholic extract of Hibiscus sabdariffa $L$ (seeds), $\mathrm{R}=$ hydroalcoholic extract of Hibiscus sabdariffa $L$ (leaves), S= hydroalcoholic extract of Caesalpinia decapetula (flowers), $T=$ dried fruit juice of Phyllanthus emblica, $\mathrm{ADR}=$ Adriamycin (standard drug). All the experiments were performed in triplicate 


\section{GC-EI/MS profiling}

A GC-MS profiling was carried out to obtain qualitative information about the flowers of Caesalpinia decapetula phytoconstituents. The full scan investigation was performed to establish the chromatographic and mass characters of the various compounds. The fragmentation pattern obtained from the GC-MS was compared with the library of compounds provided by NIST. Eighteen compounds were identified by comparing their mass spectra with the mass spectral libraries (table 2). Compounds 1 to 6 , were polycyclic enones [15], broadly detected in Caesalpinia decapetula flowers. Compounds 1 to 3 and 6 gave a molecular ion peak at $\mathrm{m} / \mathrm{z}$ 226 , while compound 4 and 5 gave $\mathrm{m} / \mathrm{z}$ at 91 and 184 respectively.
Compounds 7 to 12 were identified as fatty acids. Compound 7 i.e. 11,13-Dihydroxy-tetradec-5-ynoic acid, methyl ester was previously identified in Citrullus colocynthis [16]. The other important compounds identified were cis-5,8,11,14,17-Eicosapentaenoic acid trimethylsilyl ester, which is omega 3 fatty acid and plays a vital role as an energy source, maintains membrane stability and cell signaling [17]. The compound 13 was identified as Columbin, a diterpenoid furane lactone, previously extracted from Calumbae radix reported to reduced azoxymethane-induced colon carcinogenesis gave $\mathrm{m} / \mathrm{z}$ at 358 [18]. The compound 15 was Resibufogenin, bufadienolides reported as a cytotoxic agent, reduce hypertension and proteinuria gave $\mathrm{m} / \mathrm{z}$ at 384 . The rest of the compounds were androsterone which plays a vital role in the endocrine system of the body $[19,20]$.

Table 2: GC-EI/MS data of compounds from hydroalcoholic extracts of Caesalpinia decapetula flowers

\begin{tabular}{|c|c|c|c|c|}
\hline $\begin{array}{l}\text { S. } \\
\text { No. }\end{array}$ & RT & EI/MS m/z (rel. int.) & $\mathbf{C F}$ & MW \\
\hline 1. & $\begin{array}{l}\text { 1,4a-Dimethyl-2,3,4,4a-tetrahydro-9(1H)- } \\
\text { phenanthrenone }\end{array}$ & $\begin{array}{l}\text { 226(999), 171(781), } 170(559), 211(415), 172(344), 141 \\
(326), 115 \text { (312), 158(297), } 142 \text { (269), } 128 \text { (255).| }\end{array}$ & $\mathrm{C}_{16} \mathrm{H}_{18} \mathrm{O}$ & 226 \\
\hline 2. & 2,2'-Dimethyl-6,6'-dinitro-1,1'-biphenyl & $\begin{array}{l}\text { 226(999), 91(614), 137(430), 65(280), } \\
152(244), 165(171), 227(163), 178(143), 77(128), 63 \\
(119)\end{array}$ & $\mathrm{C}_{14} \mathrm{H}_{12} \mathrm{~N}_{2} \mathrm{O}_{4}$ & 272 \\
\hline 3. & $\begin{array}{l}\text { Tetracyclo[10.2.1.0(2,11).0(4,9)]pentadeca-2(11),6,13- } \\
\text { triene-5,8-dione }\end{array}$ & $\begin{array}{l}\text { 226(999), 115(595), 128(421), 91(410), 160(405), } \\
\text { 55(376), 141(369), 39(366) 117(352), 211(314).| }\end{array}$ & $\mathrm{C}_{15} \mathrm{H}_{14} \mathrm{O}_{2}$ & 226 \\
\hline 4. & cis-1-Benzylidene-8-methylhydrindan & $\begin{array}{l}91(999), 131(526), 211(365), 226(344), 41(324), \\
129(225), 135(212), 115(197), 184(193), 77(187) .\end{array}$ & $\mathrm{C}_{17} \mathrm{H}_{22}$ & 226 \\
\hline 5. & 4a-Phenyl-4,4a,5,6,7,8-hexahydro-2(3H)-naphthalenone & $\begin{array}{l}\text { 184(999), 226(891), 141(792), 169(772), 91(663), } \\
170(604), 198(554), 115(534), 142(534), 77(465),\end{array}$ & $\mathrm{C}_{16} \mathrm{H}_{18} \mathrm{O}$ & 226 \\
\hline 6. & Bicyclo[4.3.0]nonan-2-one, 8-benzylidene-, Z,E & $\begin{array}{l}226(999), 135(632), 91(546), 155(409), 115(252), \\
117(233), 227(197), 129(175), 77(174), 128(173)\end{array}$ & $\mathrm{C}_{16} \mathrm{H}_{18} \mathrm{O}$; & 226 \\
\hline 7. & 11,13-Dihydroxy-tetradec-5-ynoic acid, methyl ester & $\begin{array}{l}\text { 45(999), 43(811), 79(618), 41(582), 55(550), 91(540), } \\
93(538), 67(528), 71(502), 81(500)\end{array}$ & $\mathrm{C}_{15} \mathrm{H}_{26} \mathrm{O}_{4}$ & 270 \\
\hline 8. & 10,12,14-Nonacosatriynoic acid & $\begin{array}{l}\text { 131(999), 129(828), 157(815), 171(766), 55(705), } \\
143(696), 43(673), 91(665), 117(663), 145(638)\end{array}$ & $\mathrm{C}_{29} \mathrm{H}_{46} \mathrm{O}_{2}$ & 426 \\
\hline 9. & $\begin{array}{l}\text { 2-[(Trimethylsilyl)oxy]-1- } \\
\text { ([(trimethylsilyl)oxy]methyl)ethyl (9E,12E,15E)- } \\
9,12,15 \text {-octadecatrienoate }\end{array}$ & $\begin{array}{l}41(999), 73(870), 55(760), 27(700), 43(700), 29(650), \\
133(550), 75(470), 149(470), 39(450)\end{array}$ & $\mathrm{C}_{27} \mathrm{H}_{52} \mathrm{O}_{4} \mathrm{Si}_{2}$ & 496 \\
\hline 10. & 1,3-Xylyl-18-crown-5, 2-(9-borabicyclo[3.3.1]non-9-yl)- & $\begin{array}{l}\text { 45(999), 131(369), 115(335), 105(278), 130(261), } \\
67(256), 129(254), 89(252), 95(221), 43(215)\end{array}$ & $\mathrm{C}_{24} \mathrm{H}_{37} \mathrm{BO}_{5}$ & 416 \\
\hline 11. & $\begin{array}{l}\text { cis-5,8,11,14,17-Eicosapentaenoic acid, trimethylsilyl } \\
\text { ester }\end{array}$ & $\begin{array}{l}79(999), 73(956), 75(848), 91(836), 117(694), 67(570), \\
93(553), 105(493), 119(474), 106(458)\end{array}$ & $\mathrm{C}_{23} \mathrm{H}_{38} \mathrm{O}_{2} \mathrm{Si}$ & 374 \\
\hline 12. & 10,12-Tricosadiynoic acid, trimethylsilyl ester & $\begin{array}{l}\text { 73(999), 75(979), 91(698), 119(641), 117(556), } \\
105(483), 133(450), 55(432), 93(362), 79(361)\end{array}$ & $\mathrm{C}_{26} \mathrm{H}_{46} \mathrm{O}_{2} \mathrm{Si}$ & 418 \\
\hline 13. & Columbin & $\begin{array}{l}44 \text { (999), } 91 \text { (234), } 79 \text { (215), } 77 \text { (180), } 94 \text { (173), } 28 \text { (164), } \\
204(164), 95 \text { (151),| } 109 \text { (149), } 105 \text { (145) }\end{array}$ & $\mathrm{C}_{20} \mathrm{H}_{22} \mathrm{O}_{6}$ & 358 \\
\hline 14. & $\begin{array}{l}\text { Acetic acid, 10,13-dimethyl-2-oxo- } \\
\text { 2,3,4,7,8,9,10,11,12,13,14,15,16,17-tetradecahydro-1H- } \\
\text { cyclopenta[a] phenanthren-17-yl ester }\end{array}$ & $\begin{array}{l}43(999), 161(599), 330(499), 105(305), 55(273), 79 \\
(270), 91(270), 93(258), 41(227), 119(212)\end{array}$ & $\mathrm{C}_{21} \mathrm{H}_{30} \mathrm{O}_{3}$ & 330 \\
\hline 15. & Resibufogenin & $\begin{array}{l}\text { 107(999), 79(754), 91(713), 55(632), 105(560), 95(549), } \\
81(509), 93(505), 67(493), 215(480)\end{array}$ & $\mathrm{C}_{24} \mathrm{H}_{32} \mathrm{O}_{4}$ & 384 \\
\hline 16. & $\begin{array}{l}\text { dl-3Beta-hydroxy-d-homo-18-nor-5alpha-androst- } \\
\text { 13(17a)-en-17-one }\end{array}$ & $\begin{array}{l}110(999), 270(419), 107(321), 91(284), 288(270), \\
109(264), 134(231), 79(220), 147(210), 160(210)\end{array}$ & $\mathrm{C}_{19} \mathrm{H}_{28} \mathrm{O}_{2}$ & 288 \\
\hline 17. & $\begin{array}{l}\text { 6,10-Methano-19-norandrost-4-ene-3,17-dione, 6- } \\
\text { methoxy- }\end{array}$ & $\begin{array}{l}314(999), 91(872), 41(629), 55(577), 105(522), 126 \\
(515), 115(514), 176(514), 113(508), 129(460)\end{array}$ & $\mathrm{C}_{20} \mathrm{H}_{26} \mathrm{O}_{3} ;$ & 314 \\
\hline 18. & $\begin{array}{l}\text { Acetic acid, 12a-methyl-7,10-dioxo- } \\
\text { 1,2,3,3a,3b,4,6,7,8,9,10,11,12,12a-tetradecahydro- } \\
\text { benzo[c]cyclopenta[h]azulen-1-yl ester }\end{array}$ & $\begin{array}{l}\text { 43(999), 288(796), 92(725), } 160(719), 91(638), \\
135(553), 28(528), 55(515), 134(501), 161(494)\end{array}$ & $\mathrm{C}_{20} \mathrm{H}_{26} \mathrm{O}_{4}$ & 330 \\
\hline
\end{tabular}

\section{DISCUSSION}

The aim of the present study is to evaluate the phytochemica composition and cytotoxicity of the herbal drugs. The detailed literature survey revealed that all the selected plants are used by traditional healers for the treatment of various disease. The phytochemical analysis of the selected plants showed the presence of various chemical constituents which are responsible to elicit the response for various pharmacological activity. The rhizomes of Dryopteris cochleata was found to be exceptionally rich in flavonoids and its analogs. The present study shows the cytotoxic effect of five extracts i.e. leaves of Hibiscus sabdariffa L., seeds of Hibiscus sabdariffa L., flowers of Caesalpinia decapetala (Roth) Alston, rhizomes of Dryopteris cochleata and dried fruit juice of Phyllanthus emblica against four cancer cell lines viz. HepG2, PC3, MCF7, and HL60. It includes $\mathrm{GI}_{50}$, TGI and $\mathrm{LC}_{50}$ values of extracts against various cancer cell lines. The cytotoxicity of the selected plant drugs was evaluated by Sulphorhodamine B assay. The dried juice of Phyllanthus emblica inhibited the HL60 cell growth in a dosedependent manner. Considering the previous reports, Phyllanthus emblica shown cytotoxicity on various other cancer cell lines of leukemia [21-23]. This is the first report of Phyllanthus emblica cytotoxicity against HL60 cancer cells. The earlier studies reported that tannins, flavonoids, triterpenoids and polyphenols present in plants are responsible for the cytotoxic effect on various human cancer cell lines [24, 25]. It is also the first study that shows the 
evaluation of flowers of Caesalpinia decapetala (Roth) Alston on cancer cell lines with nearly $50 \%$ control growth at $10 \mu \mathrm{g} / \mathrm{ml}$ dose against HL60 cancer cells. The details of chemical constituents presence in Caesalpinia decapetala (Roth) Alston was investigated using GC-MS. The columbine and resibufogenin present in Caesalpinia decapetala (Roth) Alston have previously shown cytotoxicity activity. The secondary metabolites such as steroids, terpenoids, saponins, flavonoids, polyphenolic compounds, and glycosides are responsible for pharmacological properties [26]. Although the rhizomes of Dryopteris cochleata showed a variety of flavonoids in the phytochemical analysis but was ineffective to control cell growth. It is the first study which shows the evaluation of rhizomes of Dryopteris cochleata against various cancer cell lines.

\section{CONCLUSION}

In conclusion, our study demonstrates that fruit juice of Phyllanthus emblica inhibited fifty percent of the HL60 cells at the dose of 35.6 $\mu \mathrm{g} / \mathrm{ml}$ and total cell growth at the dose of $75.8 \mu \mathrm{g} / \mathrm{ml}$. The flowers of Caesalpinia decaptala showed inhibition of HL60 cells at very low dose i.e. fifty percent of the HL60 cells were inhibited at the dose of $10 \mu \mathrm{g} / \mathrm{ml}$. The GC-MS analysis of the Caesalpinia decaptala flower extract showed the presence of androsterone, polycyclic enone, diterpenoid furanolactone and bufadienolide. The use of Caesalpinia decaptala flowers should be further investigated for in-vivo efficacy in cancer.

\section{ACKNOWLEDGEMENT}

Authors thanks, Mr. Sadhan Bhattacharya for his support in providing information about traditional medicines and Dr. Jyoti Kode to provide a facility in Tata memorial research centre, navi Mumbai for cytotoxicity testing.

\section{AUTHOR CONTRIBUTION}

The corresponding author designed the study protocol and guided in writing the research paper while presenting author performed the protocol and write the research paper.

\section{CONFLICT OF INTERESTS}

Authors declare no conflict of interest

\section{REFERENCES}

1. Kanthal LK, Naidu AVR, Lakshmi PN, Baburao Y, Bhar K. Evaluation of cytotoxic activity and anthelmintic property of chloroform extract of Clitoria ternatea l. Int J Curr Pharm Res 2016;8:73-5.

2. Kanthal LK, Bhar K, Ravali P. Evaluation of in vitro cytotoxic activity of chloroform extract of Sida acuta burm. f. Asian J Pharm Clin Res 2017;10:143-5.

3. Patwardhan B, Mashelkar RA. Traditional medicine-inspired approaches to drug discovery: can Ayurveda show the way forward?. Drug Discovery Today 2009;14:804-11.

4. American Cancer Society. Cancer facts and figures, Atlanta; 2012.

5. Globocan: Estimated cancer incidence, mortality and prevalence worldwide in 2012, International agency for the research on cancer. World health organization; 2012.

6. Zhang B, Mao G, Zheng D, Zhao T, Zou Y, Qu H, et al. Separation, identification, antioxidant, and anti-tumor activities of Hibiscus sabdariffa L. Extracts Separ Sci Technol 2014;49:1379-88.

7. Chen JH, Wang CJ, Wang CP, Sheu JY, Lin CL, Lin HH. Hibiscus sabdariffa leaf polyphenolic extract inhibits LDL oxidation and foam cell formation involving up-regulation of LXRa/ABCA1 pathway. Food Chem 2013;141:397-406.

8. Baliga MS, Dsouza JJ. Amla (Emblica officinalis Gaertn), a wonder berry in the treatment and prevention of cancer. Eur J Cancer Prev 2011;20:225-39.
9. Kathirvel A, Rai AK, Maurya GS, Sujatha V. Dryopteris cochleata rhizome: a nutritional source of essential elements, phytochemicals, antioxidants and antimicrobials. Int J Pharm Pharm Sci 2014;6:179-88.

10. Kiem PV, Minh CV, Huong HT, Lee JJ, Kim YH. Caesaldecan, a cassane diterpenoid from the leaves of Caesalpinia decapetala. Chem Pharm Bull 2005;53:428-30.

11. Vichai V, Kirtikara K. Sulforhodamine B colorimetric assay for cytotoxicity screening. Nat Protoc 2006;1:1112-6.

12. Skehan P, Storeng R, Scudiero D, Monks A, McMahon J, Vistica $\mathrm{D}$, et al. New colorimetric cytotoxicity assay for anticancer-drug screening. J Nat Cancer Inst 1990;82:1107.

13. Gaidhani SN, Singh A, Kumari S, Lavekar GS, Juvekar AS, Sen S, et al. Evaluation of some plant extracts for standardization and anticancer activity. Indian J Traditional Knowledge 2013;12:682-7.

14. Jose JK, Kuttan G, Kuttan R. Antitumour activity of Emblica officinalis. J Ethnopharmacol 2001;75:65-9.

15. Hammoumi A, Girault J, Azerad R. Microbial hydroxylation and functionalization of synthetic polycyclic enones. Tetrahedron: Asymmetry 1993;4:1295-306.

16. Idan SA, Al-Marzoqi AH, Hameed IH. Spectral analysis and antibacterial activity of methanolic fruit extract of Citrullus colocynthis using gas chromatography-mass spectrometry. Afr J Biotechnol 2015;14:3131-58.

17. Mohy El-Din SM, El-Ahwany AMD. Bioactivity and phytochemical constituents of marine red seaweeds (Jania rubens, Corallina mediterranea and Pterocladia capillacea). J Taibah Univ Sci 2016;10:471-84.

18. Kohno H, Maeda M, Tanino M, Tsukio Y, Ueda N, Wada K, et al. A bitter diterpenoid furanolactone columbin from Calumbae Radix inhibits azoxymethane-induced rat colon carcinogenesis. Cancer Lett 2002;183:131-9.

19. Vu H, Ianosi-Irimie M, Danchuk S, Rabon E, Nogawa T, Kamano Y, et al. Resibufogenin corrects hypertension in a rat model of human preeclampsia. Exp Biol Med (Maywood) 2006;231:215-20.

20. Ye M, Han J, An D, Tu G, Guo D. New cytotoxic bufadienolides from the biotransformation of resibufogenin by Mucor polymorphosporus. Tetrahedron 2005;61:8947-55.

21. Zhang YJ, Nagao T, Tanaka T, Yang CR, Okabe H, Kouno I. Antiproliferative activity of the main constituents from Phyllanthus emblica. Biol Pharm Bull 2004;27:251-5.

22. Ghosh A, Sharma A, Talukder G. Relative protection given by extract of Phyllanthus emblica fruit and an equivalent amount of vitamin C against a known clastogen-caesium chloride. Food Chem Toxicol 1992;30:865-9.

23. Rajeshkumar NV, Pillai MR, Kuttan R. Induction of apoptosis in mouse and human carcinoma cell lines by Emblica officinalis polyphenols and its effect on chemical carcinogenesis. J Exp Clin Canc Res 2003;22:201-12.

24. Ramasamy S, Wahab NA, Abidin NZ, Manickam S. Effect of extracts from Phyllanthus watsonii airy shaw on cell apoptosis in cultured human breast cancer MCF-7 cells. Exp Toxicol Pathol 2013;65:341-9.

25. Minari JB, Okeke U. Chemopreventive effect of Annona muricata on DMBA-induced cell proliferation in the breast tissues of female albino mice. Egypt J Med Hum Genet 2014;15:327-34.

26. Ashwathanarayana R, Naika R. Study on antioxidant and cytotoxic properties of olea dioica roxb. crude extract and its pure compound collected from western ghats, Karnataka, India. Asian J Pharm Clin Res 2017;10:356-67.

\section{How to cite this article}

- Ruchi Singh Thakur, Bharti Ahirwar. Ethnopharmacological evaluation of medicinal plants for cytotoxicity against various cancer cell lines. Int J Pharm Pharm Sci 2017;9(5):198-202. 